\title{
SISTEM MONITORING PENJUALAN BAHAN BANGUNAN MENGGUNAKAN PENDEKATAN KEY PERFOMANCE INDICATOR
}

\author{
Muhtad Fadly ${ }^{1}$, Dina Ros Muryana ${ }^{2}$, Adhie Thyo Priandika ${ }^{3}$ \\ Universitas Teknokrat Indonesia ${ }^{1,2,3}$
}

Email : $\underline{\text { muhtadfadly@gmail.com }}{ }^{1}$

\begin{abstract}
PT Indojava Kreasindo is one of the distributors of Kramik sanitari granite, which has a role in distributing these goods throughout the city of Lampung and its surroundings. The management of ceramic and granite sales data has been summarized in the sales recap sheet for each sales each month in writing so it takes a long time to find out the achievements of each sales each month. Therefore, the authors propose the application of sales monitoring to make it easier to find out the achievements of each sales per month. To solve this problem, we need the most effective solution, which is the Development of Monitoring Application for Building Materials Sales Using the Key Performance Indicator (KPI) Approach. In the development of this application using the waterfal method. For the data flow method using the Usacase Diagram, Activity Diagram. The concept used is monitoring using the KPI approach to facilitate the general manager in monitoring the sales of each sales. With the construction of a web-based information system and sales monitoring application aims to make it easier for the general manager to monitor the sales of each sales so that it does not require a long time and is presented in the form of a dashboard.
\end{abstract}

Keywords: Sales monitoring, KPI Approach at PT Indojava Kreasindo

\section{Abstrak}

PT Indojava Kreasindo merupakan salah satu perusahaan distributor Kramik granit sanitari, yang berperan dalam mendistribusikan barang-barang tersebut di seluruh daerah bandar lampung dan sekitarnya. Pengelolaan data penjualan keramik dan granit selama ini dirangkum dalam lembar rekap penjualan masing-masing sales setiap bulannya masih secara tertulis sehingga membutuhkan waktu yang lama untuk mengetahui pencapaian masingmasing sales setiap bulan. Oleh karena itu penulis mengusulkan aplikasi monitoring penjualan untuk mempermudah dalam mengetahui pencapaian masing-masing sales perbulan. Untuk memecahkan masalah tersebut dibutuhkan suatu solusi yang paling efektif yaitu Pengembangan Aplikasi Monitoring Penjualan Bahan Bangunan Menggunakan Pendekatan Key Perfomance Indicator (KPI) . Dalam pembangunan aplikasi ini menggunakan metode waterfal. Untuk metode aliran data menggunakan Usacase Diagram, Activity Diagram. Konsep yang digunakan yaitu monitoring menggunakan pendekatan KPI untuk memudahkan general manager dalam memantau penjualan masing-masing sales.Dengan dibangunnya sistem informasi berbasis web dan aplikasi Monitoring penjualan ini bertujuan untuk mempermudah bagi general manager memantau penjualan masing-masing sales sehingga tidak membutuhkan waktu yang lama dan disajikan dalam bentu dashboard.

Kata Kunci: Monitoring penjualan, Pendekatan KPI pada PT Indojava Kreasindo

\section{PENDAHULUAN}

PT Indojava Kreasindo merupakan salah satu perusahaan distributor Kramik granit sanitari, yang berperan dalam mendistribusikan barang-barang tersebut di seluruh daerah bandar lampung dan sekitarnya. Tujuan didirikannya PT Indojava Kreasindo adalah untuk memastikan distribusi Kramik Granit sanitari benarbenar terdistribusi didaerah Lampung dan sekitarnya. Untuk memastikan tercapainya tujuan tersebut maka kinerja karyawan pada PT Indojava Kreasindo divisi sales atau marketing benar-benar diawasi oleh General Manager dalam memantau kinerjanya dalam penjualan. Proses pemantauan kinerja penjualan tersebut dilakukan dengan menggunakan perhitungan Key Perfomance Indicator (KPI) di divisi sales. KPI merupakan sekumpulan pengukuran yang disusun secara terfokus pada aspek kinerja organisasi yang dianggap paling kritis atau penting demi suksesnya organisasi di masa sekarang maupun di masa yang akan datang (Parmeter, 2014). Proses seperti inilah yang diperlukan bagi perusahaan dalam memonitoring kinerja karyawannya.

Monitoring dapat digunakan untuk membantu dalam mengingatkan organisasi ketika terjadi masalah dan membantu agar pekerjaan tetap pada jalurnya (Suidah \& Irvan Sidni, 2018). Monitoring bertujuan untuk meningkatkan efektifitas dan efisiensi sebuah pelaksanaan kegiatan yang didasarkan pada perencanaan kegiatan, monitoring juga memungkinkan organisasi untuk menentukan apakah sumber daya yang dimiliki telah 
mencukupi dan telah digunakan dengan baik. Monitoring penjualan juga dapat dilakukan dengan megembangkan sistem dashboard penjualan interaktif yang mampu menampilkan visualisasi monitoring penjualan dalam periode tertentu (Sulistiani, 2018), sehingga mampu membantu pimpinan dalam memantau hasil penjualan dan kinerja dari karyawannya (Zainal, 2012).

Pengelolaan data penjualan keramik dan granit selama ini dirangkum dalam lembar rekap penjualan masing-masing sales setiap bulannya, kemudian data penjualan tersebut diajukan kepada General Manager, setelah General Manager menerima pengajuan hasil penjualan masing-masing sales, General Manager akan menghitung secara tertulis menggunakan perhitungan KPI untuk mengetahui pencapaian secara langsung penjualan masing-masing sales dan untuk menentukan bonus diluar gaji (insentif) yang diterima masing-masing sales dalam mencapai target penjualan, setelah data penjualan dihitung oleh General Manager setelah itu hasil perhitungan akan disimpan ke system, dari proses tersebut terdapat kendala diantaranya, pertama dengan perhitungan score KPI secara tertulis membuat pemantauan penjualan menjadi tidak efektif dikarenakan banyaknya data penjualan yang harus dihitung secara tertulis menyebabkan terselipnya nominal dalam perhitungan, kedua sebagai penunjang pengambilan keputusan dibutuhkan dashboard untuk memudahkan General Manager dalam memantau hasil penjualan (Rasmussen, 2009).

\section{METODE PELAKSANAAN}

\section{Tempat dan Waktu}

Kegiatan ini dilaksanakan di PT Indojava Kreasindo Bandar Lampung dan jangka waktu pelaksanaannya dimulai dari bulan September 2018 hingga Februari 2019.

\section{Khalayak Sasaran}

Kegiatan pengbdian ini melibatkan para staff dan karyawan PT Indo Java Kreasindo.

\section{Metode Pengabdian}

Tahap awal yang dilakukan pada penelitian ini adalah menentukan masalah yang akan diteliti. setelah menentukan masalah yang akan diteliti, maka tahap selanjutnya adalah menentukan tujuan yang ingin dicapai dalam penelitian ini. Setelah itu, melakukan pengumpulan data dengan cara wawancara, tinjauan pustaka, dan dokumentasi. Tahap selanjutnya adalah merancang sistem dan tampilan, yang meliputi Usecase Diagram, Activity Diagram, Class Diagram dan Squence Diagram (Pressman, 2012). Tahap selanjutnya adalah melakukan koding menggunakan bahasa pemrograman PHP (Kadir, 2009), dan akan diuji menggunakan Black box (Rossa \& Shalahuddin, 2015) dan Software Tester. Tahap terakhir yaitu peneliti mengimplementasikan sistem kepada user.

\section{HASIL DAN PEMBAHASAN}

Hasil pembahasan ini menggunakan metode pengumpulan data yaitu pengamatan, wawancara, tinjauan pustaka, dan dokumentasi.

\section{Desain Sistem}

Desain sistem merupakan tahap yang menentukan proses dan data yang diperlukan oleh sistem baru. Desain sistem ini merupakan gambaran secara menyeluruh mengenai urutan pengolahan data dari persiapan desain sistem sampai menghasilkan laporan yang dibutuhkan.

\subsection{Usecase Diagram}

Usecase diagram merupakan pemodelan untuk kegiatan pada sistem yang akan dibuat. Sistem memiliki 2 aktor yaitu General manager (pimpinan) dan bagian admin. 


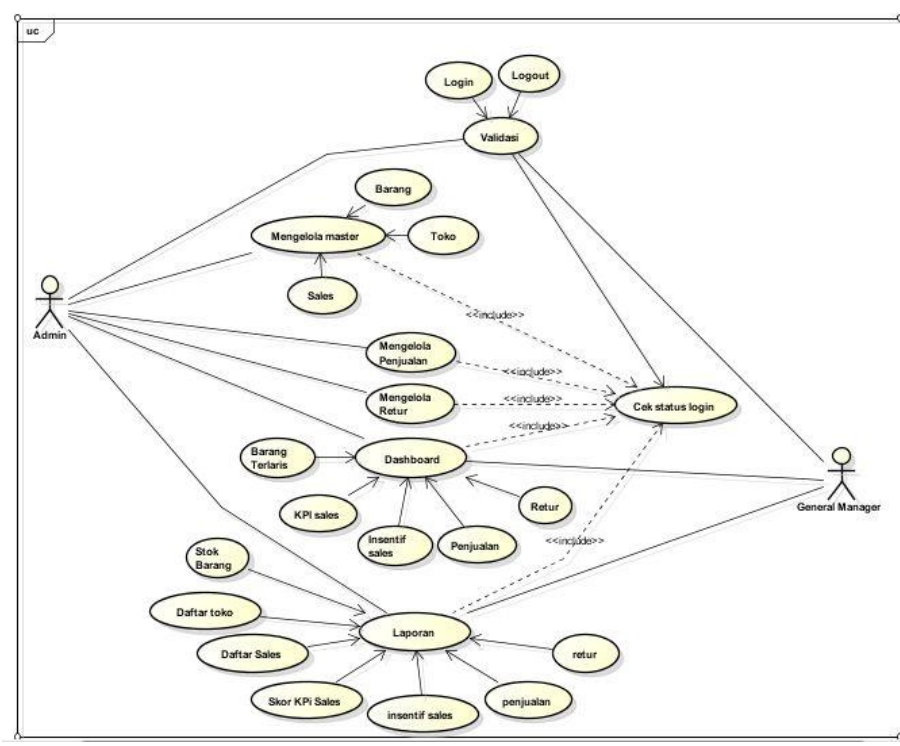

Gambar 1. UsecaseDiagram

\subsection{Activity Diagram}

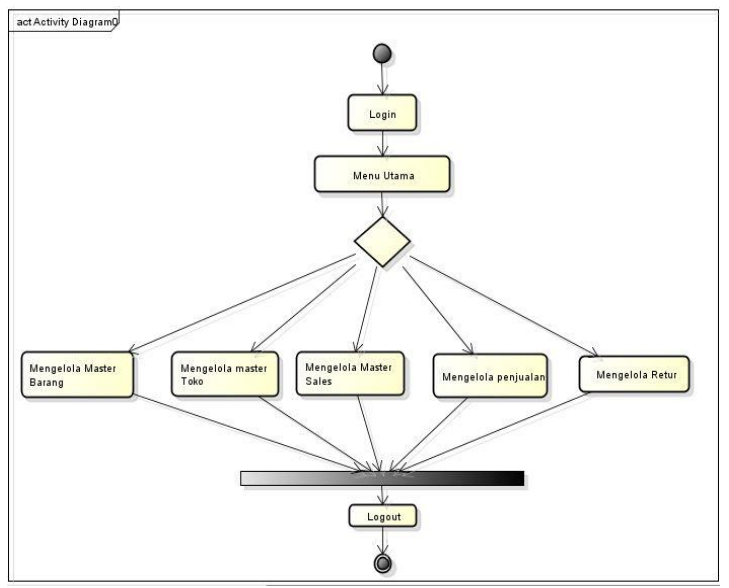

Gambar 2. Activity Diagram Admin

\subsection{Class Diagram}

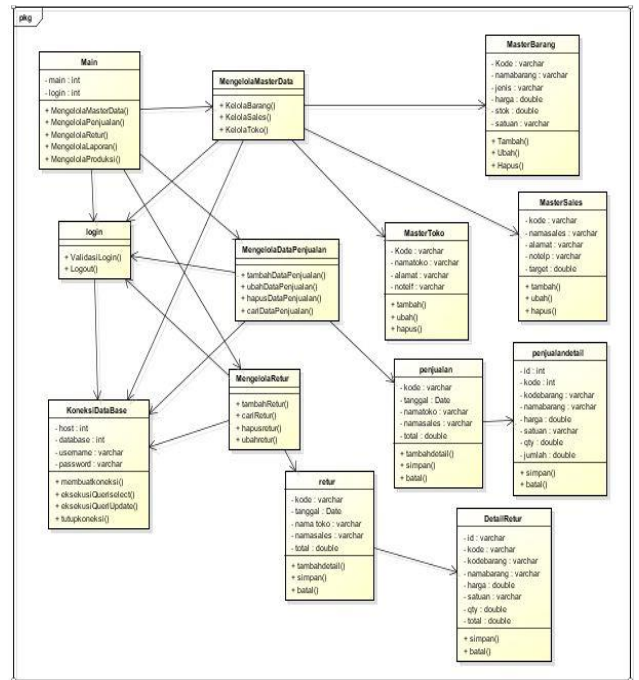

Gambar 3. Class Diagram 


\section{Tampilan Program}

\subsection{Tampilan Menu Utama}

Pada halaman menu utamadalam website ini merupakan tampilan beranda mengenai Keseluruhan dan garis besar mengenai isi-isi juga menu yang bisa diakses oleh admin, Adapun tampilannya dapat :

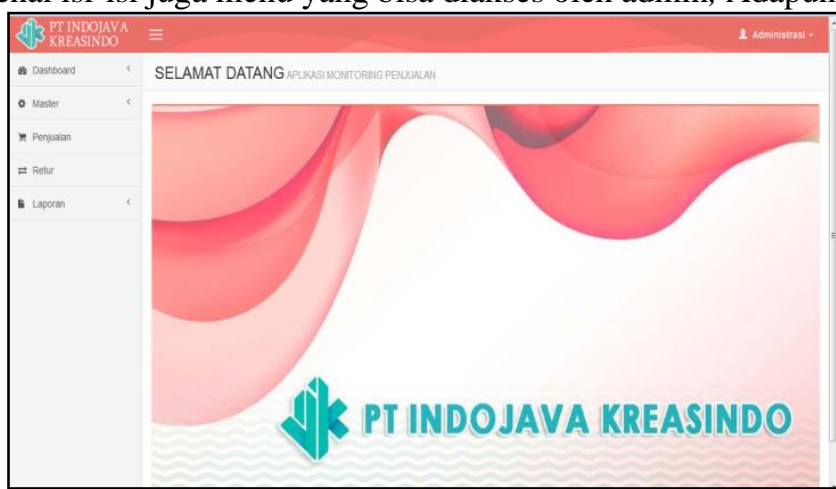

Gambar 4. Menu Utama Admin

\subsection{Menu Master}

Form menu master toko, barang dan sales digunakan untuk menginput toko, barang dan sales yang baru atau belum pernah diinputkan sebelumnya, dapat dilihat pada gambar 5 .

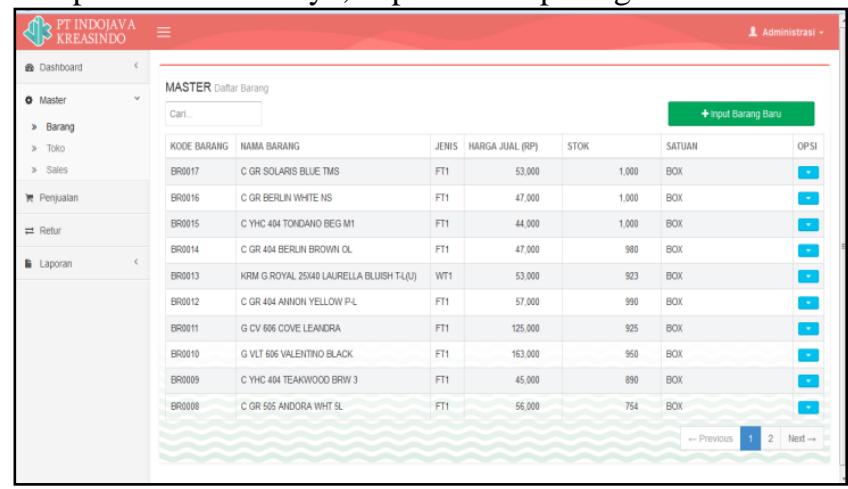

Gambar 5. Menu Master

\subsection{Menu Transaksi}

Menu Transaksi Penjualan dan Retur yaitu menu yang digunakan untuk transaksi penjualan dan retur barang yang telah dijual dan dikembalikan oleh peruusahaan, dapat dilihat pada gambar 6 .

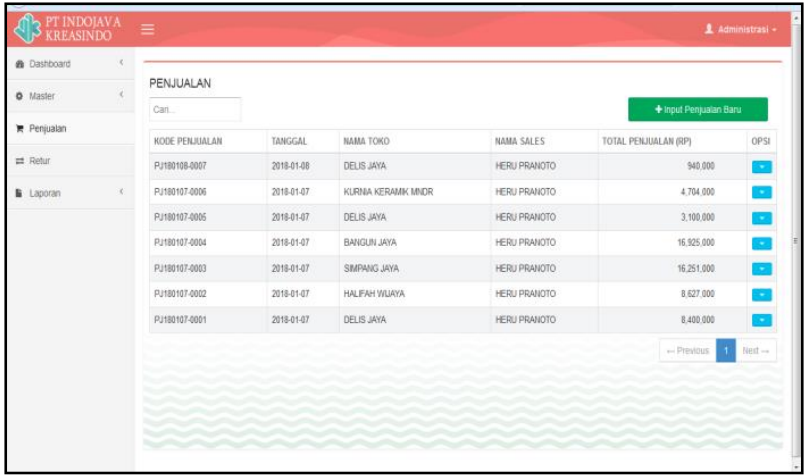

Gambar 6. Menu Transaksi

\subsection{Menu Sekor KPI Sales}

Menu yang diguanakan untuk melihat sekor pencapaian dari masing-masing sales, dapat dilihat pada gambar 7. 


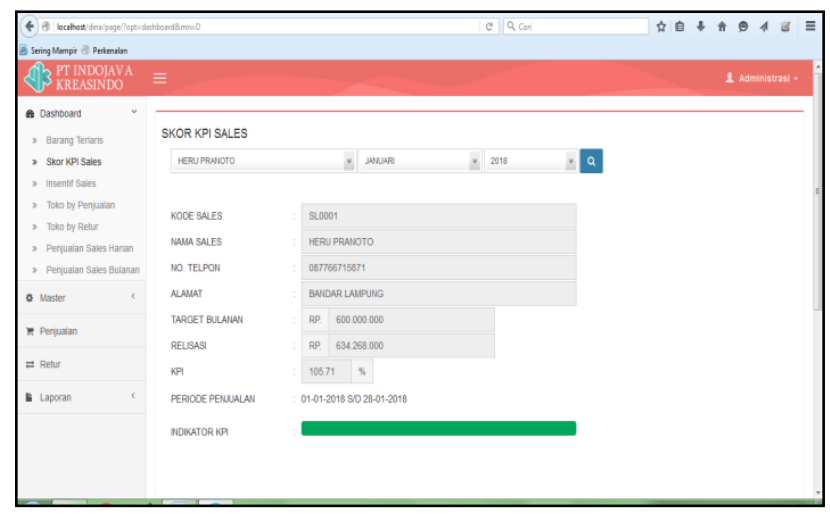

Gambar 7. Menu Sekor KPI Sales

\subsection{Menu Insentif Sales}

Menu insentif sales digunakan untuk melihat berapa banyak insentif yang diterima oleh sales dari penjualan barang, dapat dilihat pada gambar 8.

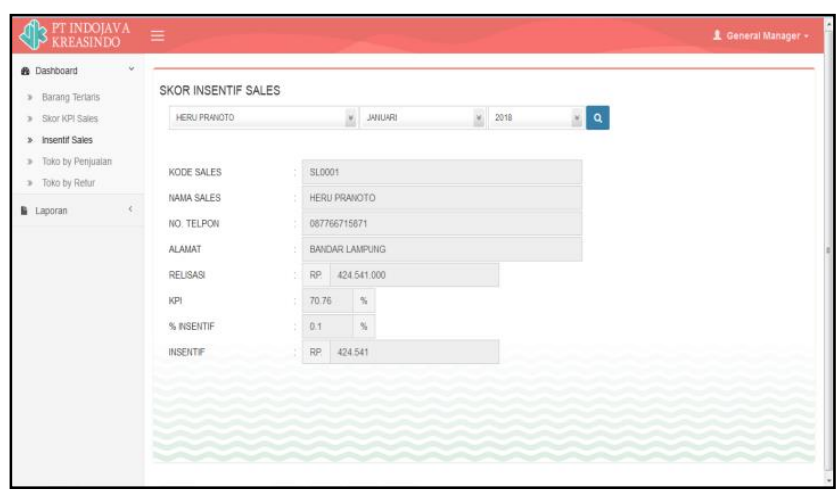

Gambar 8. Menu Insentif Sales

\subsection{Dashboard penjualan perbulan}

Antarmuka yang memudahkan bagi general manager untuk memantau pencapaian penjualan perbulan dalam waktu 1 tahun penjualan, dapat dilihat pada gambar 9.

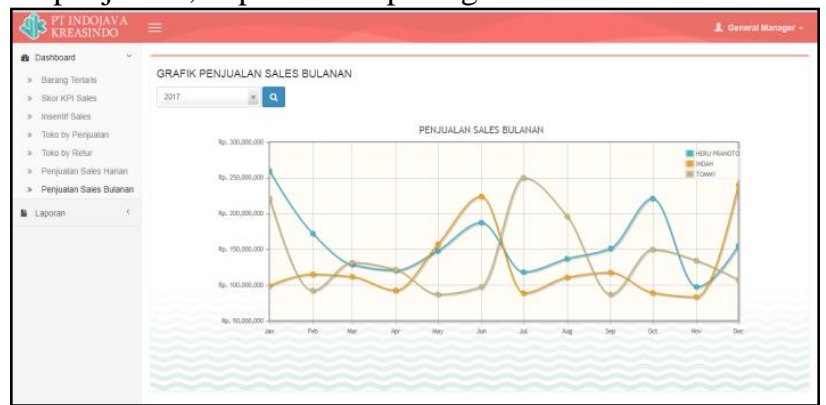

Gambar 9. Dashboard penjualan perbulan

\subsection{Halaman Cetak Laporan}

Antarmuka yang memudahkan general manager untuk mengetahui laporan dari transaksi penjualan. dapat dilihat pada gambar 10 . 


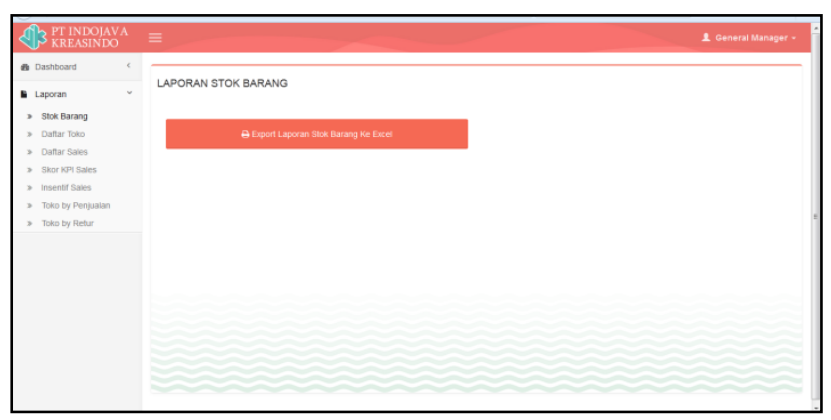

Gambar 10 Halaman Cetak Laporan

\section{KESIMPULAN}

Berdasarkan uraian dari bab-bab sebelumnya penulis menarik kesimpulan dan saran yaitu:

1. Dalam memonitoring penjualan pada PT Indojava Kreasindo melakukan perhitungan pencapaian perbulan masing-masing sales berdasarkan penjualan yang dilakukan oleh sales tersebut, sehingga dibutuhkannya pengembangan aplikasi monitoring penjualan bahan bangunan untuk memudahkan bagi general manager untuk mengetahui pencapaian masing-masing sales dan sebagai penunjang pengambilan keputusan bagi general manager.

2. Penerapan pendekatan Key Perfomance Indicator (KPI) yaitu dengan menentukan realisasi dan target dari masing-masing sales, setelah itu sistem akan menghitung secara terkomputerisasi dengan rumus KPI setelah itu akan menghasilkan persentase pencapaian KPI beserta tampilan dashboard.

3. Pengembangan sistem monitoring penjualan yang digunakan akan membantu memudahkan bagi general manager dalam melihat persentase pencapaian penjualan, sistem yang dibangun dengan metode pengembangan sistem waterfall dan dalam mengoptimalkan pengolahan data maka dilakukan perancangan dengan alat pengembangan sistem UML(Unified Modeling Language). Setelah dilakukan tahap perancangan, implementasi sistem menggunakan bahasa pemograman PHP dan database MySQL, serta melakukan pengujian menggunakan blackbox dan software tester. Sehingga dapat menjadi acuan bagi general manager dalam pengambilan keputusan.

\section{REFERENSI}

Kadir, A. 2009. From Zero to A Pro : Membuat Aplikasi Web dengan PHP dan database MySQL.Yogyakarta : Andi Offset. Parmenter, D. 2014. Key Performance Indicators (KPI). Jakarta: PPM.

Pressman, R. S. 2012. Rekayasa Perangkat Lunak. Yogyakarta: Andi.

Rasmussen, Bansal, \& Chen. 2009. Business Dashboards : A Visual Catalog for Design and Development. New Jersey: John Wiley \& Sons.

Rosa, A. S., \& Shalahuddin, M. 2015. Rekayasa Perangkat Lunak. Bandung: Informatika.

Suaidah dan Irvan Sidni. 2018. Perancangan Monitoring Prestasi Akademik dan Aktivitas Siswa Menggunakan Pendekatan Key Performance Indikator (Studi Kasus: SMA N 1 Kalirejo). Jurnal Tekmo Kompak, Vol. 12 No. 22018.

Sulistiani, Heni. 2018. Perancangan Dashboard Interaktif Penjualan (Studi Kasus: PT Jaya Bakery). Jurnal Tekno Kompak, Vol. 12 No, 1, 2018.

Zainal, A. 2012. Rancang Bangun Perangkat Lunak Performance Dashboard Evaluasi Kinerja Karyawan Rumah Sakit Umum Pemerintah Dengan Metode The Malcom Baldrige National Quality Award (MBNQA).0076-8. 